\title{
KAJIAN MUTU KIMIA DAN ORGANOLEPTIK TELUR AYAM KAMPUNG DENGAN EKSTRAK ETANOL Sargassum crassifolium SEBAGAI ANTIMIKROBA ALAMI
} [Study of Chemical and Organoleptic Quality of Village Chicken Eggs With Ethanol Extract of Sargassum crassifolium
As A Natural Antimicrobial]

\section{Moegiratul Amaro', Mutia Devi Ariyana ${ }^{1}$, Wiharyani Werdiningsih ${ }^{1}$, Baiq Rien Handayani ${ }^{1}$, Nazaruddin ${ }^{1}$, Sri widyastuti ${ }^{1}$}

\author{
1)Program Studi Ilmu dan Teknologi Pangan \\ Fakultas Teknologi Pangan dan Agroindustri Universitas Mataram \\ *email: moegiratulamaro@unram.ac.id
}

Diterima 19 Februari 2021 / Disetujui 6 April 2021

\begin{abstract}
The aim of this research was to determine the effect of the concentration and soaking time of Sargassum crassifolium ethanol extract as a natural antimicrobial on the chemical and organoleptic quality of native chicken eggs. This research was an experimental study using a factorial completely randomized design consisting of 2 factors, those were the concentration of the ethanol extract of S. crassifolium (0\%,20\%,40\% and 60\%) and the soaking time (30,60 and 90 minutes). The results showed that soaking chicken eggs with ethanol extract of S. crassifolium had no significant effect on the $\mathrm{pH}$ of egg yolks and whites and flavour content egg. The best treatment was obtained from the soaking treatment with a concentration of $20 \%$ ethanol extract of S. crassifolium with soaking time for 60 minutes, where the appearance of a typical egg color and preferred by the panelists, the characteristic flavour egg shell and preferred by the panelists and the flavour of the egg contents which did not smell like seaweed and preferred by panelist.
\end{abstract}

Key words: Natural antimicrobial, chemical quality, organoleptic quality, Sargassum crassifolium, chicken eggs

\section{ABSTRAK}

Tujuan penelitian ini adalah untuk mengetahui pengaruh konsentrasi dan lama perendaman ekstak etanol Sargassum crassifolium sebagai antimikroba alami terhadap mutu kimia dan organoleptik telur ayam kampung. Penelitian ini adalah penelitian eksperimental menggunakan Rancangan Acak Lengkap faktorial yang terdiri dari 2 faktor yaitu konsentrasi ekstrak etanol S. crassifolium (0\%, 20\%, 40\% dan 60\%) dan lama perendaman (30,60 dan 90 menit). Hasil penelitian menunjukkan bahwa perendaman telur ayam kampung dengan ekstrak etanol $S$. crassifolium memberikan pengaruh yang tidak berbeda nyata terhadap pH kuning dan putih telur dan aroma isi telur tetapi memberikan pengaruh berbeda nyata terhadap kenampakan cangkang telur. Perlakuan terbaik diperoleh dari perlakuan perendaman dengan konsentrasi $20 \%$ ekstrak etanol $S$. crassifolium dengan lama perendaman selama 60 menit, dimana diperoleh kenampakan warna khas telur dan disukai panelis, aroma cangkang khas telur dan disukai panelis serta aroma isi telur yang tidak beraroma rumput laut dan disukai panelis.

Kata kunci: Antimikroba alami, mutu kimia, mutu organoleptik, Sargassum crassifolium, Telur ayam kampung

\section{PENDAHULUAN}

Dibandingkan dengan daging dan ikan, masyarakat pada umumnya lebih memilih telur sebagai sumber protein hewani. Selain karena harganya yang terjangkau, telur juga mudah diperoleh (Sarwono, 1995). Keunggulan yang dimiliki telur diantaranya kandungan gizi yang lengkap, mudah dicerna, serta harganya relatif murah (Hiroko dkk., 2014).

Pada umumnya telur yang dikonsumsi oleh masyarakat Indonesia adalah yang berasal 
Versi Online:

http://Www.profood.unram.ac.id/index.php/profood e-ISSN: 2443-3446

dari unggas yang diternakkan yaitu ayam boiler, ayam kampung, bebek dan puyuh. Ayam kampung yang lebih dikenal dengan ayam buras, adalah ternak lokal yang telah menjadi bagian dari kehidupan masyarakat pedesaan di Indonesia. Telur ayam kampung adalah telur yang dihasilkan dari ayam kampung dan memiliki banyak keunggulan dibandingkan telur ayam ras (Sulistiati, 2003). Telur ayam kampung memiliki khasiat bagi tubuh dan sering dikonsumsi mentah dicampur dengan madu dan dipercaya untuk meningkatkan stamina. Oleh karena itu telur ayam kampung lebih disukai oleh masyarakat (Diaz, 2008). Telur ayam kampung mengandung zat-zat yang sangat dibutuhkan oleh tubuh manusia seperti protein dengan asan amino yang lengkap, lemak, vitamin, mineral, serta memiliki daya cerna yang tinggi (Sulistiati, 2003).

Masyarakat Indonesia percaya bahwa mengkonsumsi telur ayam kampung mentah baik untuk kesehatan, tetapi dari segi keamanan pangan sangat berbahaya karena telur ayam mentah banyak mengandung cemaran. Telur ayam kampung adalah salah satu bahan pangan yang beresiko besar terkontaminasi mikroba secara langsung maupun tidak langsung. Kontaminasi telur pada umumnya berasal dari udara, tanah, jerami tempat bertelur dan kotoran ayam itu sendiri (Finata dkk, 2015). Telur ayam kerupakan media yang sangat baik untuk pertumbuhan mikroba karena telur kaya akan nutrisi yang penting untuk pertumbuhannya. Jika mikroba tumbuh dan berkembang biak dengan cepat maka daya simpan telur menjadi pendek, telur akan cepat mengalami kerusakan dan kebusukan. Selain itu, mikroba pathogen dapat berbahaya terhadap kesehatan dan menyebabkan keracunan pada konsumen ketika telur tidak mendapat penanganan yang baik pada saat pengolahan atau pun ketika dikonsumsi dalam keadaan mentah. Telur rentan terkontaminasi mikroba karena sifatnya yang mudah rusak atau retak (fragile) sehingga menyebabkan telur cepat mengalami kerusakan dan kebusukan (Afiyah dan Rahmawati, 2017).
Pro Food (Jurnal Ilmu dan Teknologi Pangan)

Vol 7 No. 1 Mei 2021

ISSN: 2443-1095
Mikroorganisme menyebabkan
kerusakan biologis pada telur antara lain Salmonella sp, Stapylococcus aureus dan Escerechia coli. Dalam keadaan tertentu, mikroba tersebut dapat berkembang biak melebihi batas normal sehingga dapat menyebabkan keracunan bagi orang yang mengkonsumsi (Chusniati dkk., 2009). Kontaminasi telur dapat terjadi melalui du acara yaitu vertikal dan horizontal. Cemaran yang berasal dari induk ayam yang terinfeksi disebut cemaran vertikal atau transovarial, sedangkan cemaran yang terjadi di luar tubuh induk ayam disebut cemaran horizontal. Cemaran horizontal terjadi berawal masuknya bakteri ke dalam telur misalnya berasal dari kotoran yang menempel pada kulit telur seperti debu, tanah, dan feses (Omwandho dan Kubota, 2010). Pori-pori kulit telur merupakan tempat potensial terjadinya proses pencemaran. Semakin lama penyimpanan maka akan semakin meningkatkan jumlah mikroba pencemar (Nurjanna, 2015).

Salah satu cara untuk mengurangi cemaran mikroba pada telur adalah dengan membersihkan dan mengemas telur sebelum dipasarkan (Djafar, 2007). Cangkang telur biasanya dibersihkan melalui proses pencucian. Proses ini dapat menghilangkan bakteri perusak yang terdapat di sekitar cangkang telur (Haryoto, 1996). Selain itu, tindakan disinfeksi juga dapat mengurangi jumlah cemaran mikroba pada telur. Desinfektan yang sering digunakan antara lain klorin dan quats. Penggunaan klorin sebagai sanitizer kimia memberikan dampak kurang baik seperti gangguan saluran pernafasan dan iritasi mata (King et al, 2004). Oleh karena itu perlu dicari senyawa antimikroba lain yang aman, ramah lingkungan, dan efektif seperti senyawa antimikroba yang berasal dari bahan alam.

Ekstrak Sargassum crassifolium merupakan salah satu bahan alami yang dapat dimanfaatkan sebagai antimikroba alami. Penelitian terdahulu melaporkan Sargassum $s p$. merupakan salah satu bahan alami yang emiliki metabolit bioaktif senyawa antibakteri. Sargassum sp. mengandung tannin, iodin, dan 
Versi Online:

http://Www.profood.unram.ac.id/index.php/profood e-ISSN: 2443-3446

fenol yang dapat berperan sebagai zat amaropembusuk dan pathogen (Sastry dalam Bachtiar, 2012). Amaro dkk (2018) juga melaporkan ekstrak Sargassum crassifolium dari perairan NTB dengan pelarut etanol mengandung alkaloid, triterpenoid, dan saponin serta kandungan antioksidan sebesar 9,3\%. Baleta et al (2017) juga melaporkan ekstrak Sargassum crassifolium dengan pelarut etanol mengandung flavonoid, tanin, fenolik, dan terpenoid. Fenol dapat berperan dalam proses denaturasi protein dan merusak membran sel (Rahayu, 2000). Ekstrak Sargassum $s p$ dengan pelarut etanol bersifat bakteriostatik dan mempunyai aktifitas menghambat yang dapat menghambat pertumbuhan E.colisebesar $7 \mathrm{~mm}$ (Baleta, 2017). Ekstrak rumput laut $S$. crassifolium pada konsentrasi $10 \%$ memiliki pH sekitar 8 dan mengandung bahan aktif asam uronat $0,90 \%$ yang dapat menghambat dan menyebabkan kematian bakteri Salmonella sp (Kereh, 2018).

\section{BAHAN DAN METODE}

\section{Bahan dan Alat}

Bahan-bahan yang digunakan dalam penelitian ini adalah $S$. crassifolium yang diambil dari perairan Pantai Sumbawa, telur ayam kampung (24-48 jam, Buffered Peptone Water (BPW), ethanol 96\%, air, natrium hipoklorit 1\%, aquades steril.

Alat-alat yang digunakan dalam penelitian ini adalah gelas ukur, gunting, ember plastik, oven (GEA GETRA, Indonesia), kertas saring Whatman's, mesin stirrer, timbangan analitik, rotary evaporator (Scilogex, Amerika Serikat), kantong plastik, kain tipis, inkubator (Memmert, Indonesia), pipet mikro $100 \mu \mathrm{L}$, bunsen, tabung reaksi, rak tabung reaksi.

\section{Metode}

Metode yang digunakan dalam penelitian ini adalah metode eksperimental yang dilaksanakan di laboratorium.
Pro Food (Jurnal Ilmu dan Teknologi Pangan)

Vol 7 No. 1 Mei 2021

ISSN: 2443-1095

\section{Pelaksanaan penelitian: \\ Pembuatan Ekstrak Rumput Laut Sargassum crasifolium}

Diagram alir penelitian proses pembuatan ekstrak S. Crassifolium tertera pada Gambar 1.

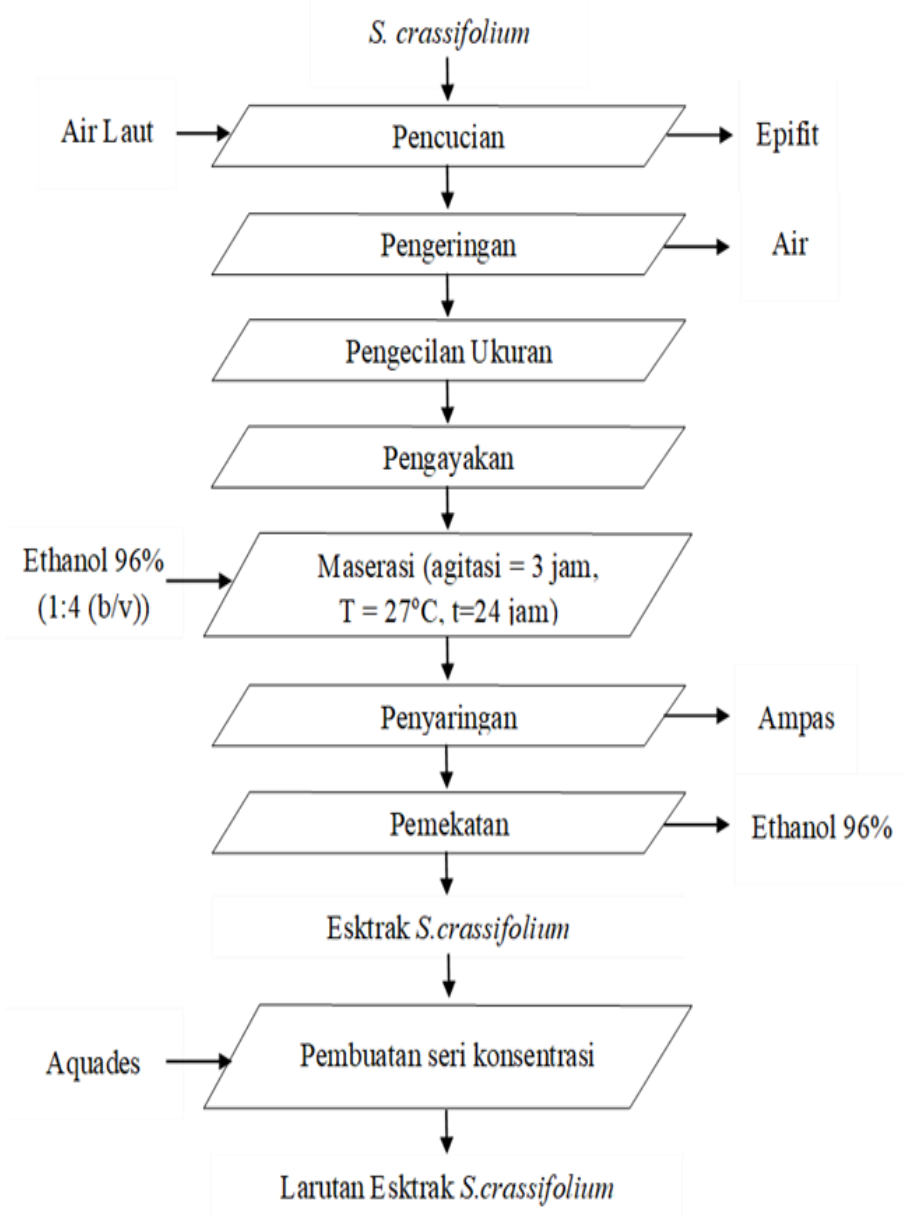

Gambar 1. Diagram Alir Proses Ekstraksi Modifikasi Metode Kereh (2018) 


\section{Pengaplikasian Ekstrak $\boldsymbol{S}$. crassifolium sebagai Antimikroba Telur Ayam Konsumsi}

Diagram alir penelitian proses pengujian tertera pada Gambar 2.

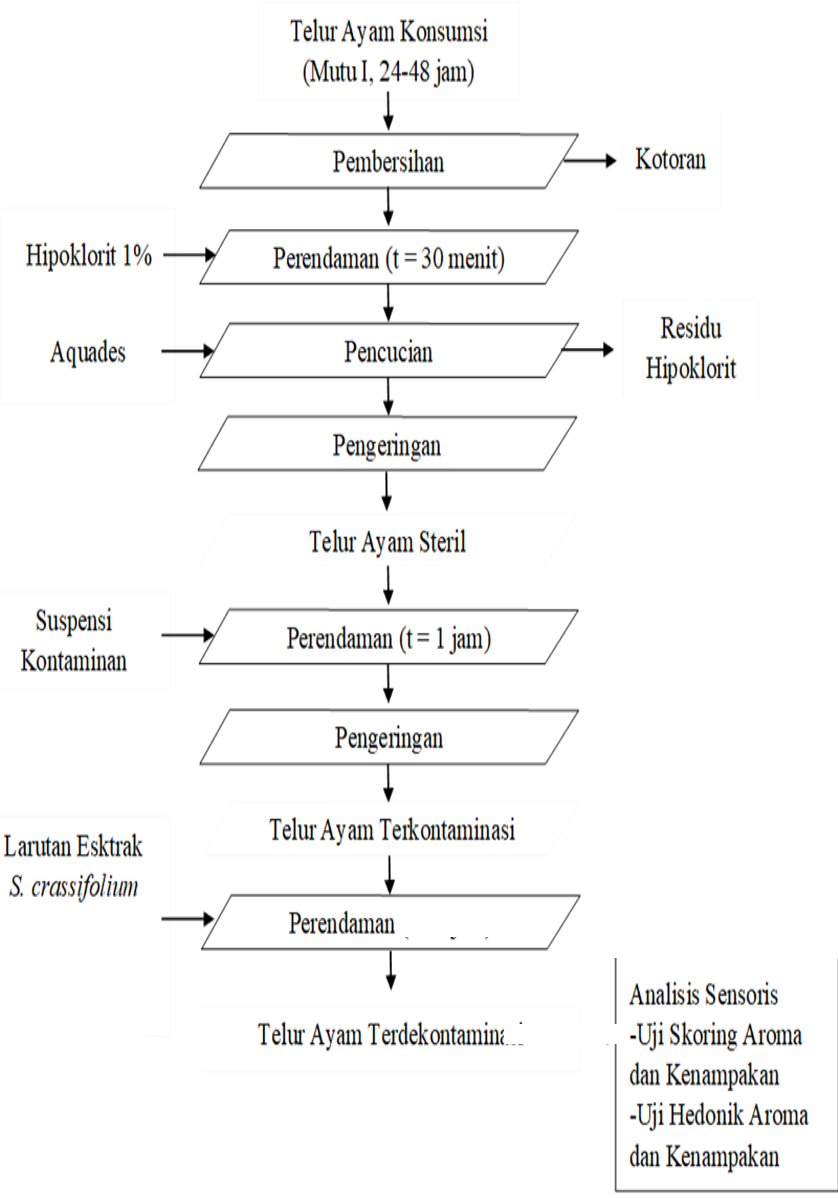

Gambar 2. Diagram Alir Penelitian Proses Pengujian Modifikasi Metode Tayel (2018)

Rancangan percobaan yang digunakan pada penelitian adalah Rancangan Acak Lengkap faktorial yang terdiri dari 2 faktor. Faktor pertama yaitu konsentrasi ekstrak etanol $S$. crassifolium dengan 4 taraf yaitu:

K1 : $0 \%$ ekstrak etanol S. crassifolium

K2 : $20 \%$ ekstrak etanol $S$. crassifolium

K3 : $40 \%$ ekstrak etanol $S$. crassifolium

K4 : $60 \%$ ekstrak etanol $S$. crassifolium
Faktor kedua yaitu lama perendaman dengan 3 taraf yaitu:

$\mathrm{T} 1: 30$ menit

T2 : 60 menit

T3 : 90 menit

Masing-masing perlakuan diulang sebanyak 3 kali sehingga diperoleh 36 unit percobaan. Data hasil pengamatan dianalisis keragaman (Analysis of Variance) dengan taraf nyata $5 \%$ dengan menggunakan software Costat. Apabila terdapat beda nyata, dilakukan uji lanjut Beda Nyata Jujur. Analisa yang dilakukan pada telur ayam konsumsi adalah Analisa kimia $(\mathrm{pH})$ dan analisa organoleptik (aroma dan kenampakan) pada cangkang dan isi telur dengan menggunakan uji skoring dan hedonik.

\section{HASIL DAN PEMBAHASAN}

\section{Mutu Kimia pH Isi Telur}

Hubungan konsentrasi dan lama perendaman Ekstrak Etanol $S$. crassifolium terhadap Nilai pH isi telur Ayam Kampung dapat dilihat pada Tabel 1.

Tabel 1 menunjukkan hubungan antara konsentrasi dan lama perendaman ekstrak $S$. crassifolium terhadap $\mathrm{pH}$ putih dan kuning telur. Dari Tabel 1 dapat diamati bahwa $\mathrm{pH}$ kuning telur berkisar antara 6,17 hingga 6,76. $\mathrm{pH}$ tertinggi diperoleh dari perlakuan perendaman dengan konsentrasi $60 \%$ dengan lama perendaman 30 menit sedangkan $\mathrm{pH}$ terendah diperoleh dari perlakuan perendaman $0 \%$ selama 90 menit. Konsentrasi dan lama perendaman telur ayam kampung dengan ekstrak $S$. crassifolium tidak banyak merubah $\mathrm{pH}$ kuning telur. Nilai pH kuning telur masih berkisar antara 6-7 yang menunjukkan $\mathrm{pH}$ telur masih berada direntang $\mathrm{pH}$ netral. 
Versi Online:

http://www.profood.unram.ac.id/index.php/profood e-ISSN: $2443-3446$

Tabel 1. Pengaruh Konsentrasi dan Lama Perendaman Ekstrak Etanol Sargassum crassifolium Terhadap Nilai pH Telur Ayam Kampung

\begin{tabular}{|l|c|r|r|}
\hline \multirow{2}{*}{$\begin{array}{c}\text { Konsentrasi } \\
(\%)\end{array}$} & $\begin{array}{c}\text { Waktu } \\
\text { Perendaman } \\
\text { (Menit) }\end{array}$ & \multicolumn{2}{|c|}{ Nilai pH Telur } \\
\cline { 3 - 4 } & 30 & 6,75 & 8,17 \\
\hline 0 & 60 & 6,37 & 8,66 \\
\hline & 90 & 6,17 & 8,83 \\
\hline & 30 & 6,52 & 8,83 \\
\hline 20 & 60 & 6,28 & 8,86 \\
\hline & 90 & 6,38 & 8,85 \\
\hline & 30 & 6,24 & 8,76 \\
\hline 40 & 60 & 6,44 & 8,63 \\
\hline & 90 & 6,23 & 8,81 \\
\hline 60 & 30 & 6,76 & 8,7 \\
\hline & 60 & 6,56 & 8,83 \\
\hline & 90 & 6,19 & 8,77 \\
\hline
\end{tabular}

Tabel 1 juga menunjukkan pengaruh perendaman ekstrak $S$. crassifolium dengan berbagai konsentrasi dan lama perendaman terhadap $\mathrm{pH}$ putih telur ayam kampung. $\mathrm{pH}$ putih telur berkisar antara 8,17 hingga 8,86. Nilai pH tertinggi diperoleh dari perlakuan perendaman $20 \%$ selama 60 menit, sedangkan $\mathrm{pH}$ terendah diperoleh dari perlakuan perendaman $0 \%$ selama 30 menit.

Perendaman ekstrak $S$. crassifolium sedikit menaikkan $\mathrm{pH}$ putih telur tetapi masih berada pada rentang 8-9 yang menunjukkan putih telur sedikit basa. Perendaman telur dengan ekstrak $S$. crassifolium tidak berpengaruh nyata terhadap perubahan $\mathrm{pH}$ kuning maupun putih telur ayam kampung karena ekstrak $S$. crassifolium tidak dapat menembus masuk ke dalam isi telur karena dilindungi oleh lapisan membran. Lapisan membrane merupakan bagian lapisan kulit telur yang terdalam, terdiri atas dua lapisan selaput yang berbentuk seperti kertas perkamen. Lapisan ini menyelubungi seluruh isi telur, tebalnya sekitar 65 mikron yang terbuat
Pro Food (Jurnal Ilmu dan Teknologi Pangan)

Vol 7 No. 1 Mei 2021

ISSN: 2443-1095

dari keratin. Semakin ke arah bagian yang tumpul semakin menebal (Stadelman dan Cotteril, 1973).

\section{Mutu Organoleptik}

Hasil analisis uji lanjut mutu organoleptik meliputi komponen kenampakan cangkang, aroma cangkang dan aroma isi telur baik secara hedonik maupun skoring dapat diamati pada Tabel 2.

Tabel 2. Signifikansi Pengaruh Konsentrasi dan Lama Perendaman Ekstrak Etanol $S$. crassifolium Terhadap Sifat Sensoris Telur Ayam Kampung Konsumsi

\begin{tabular}{llcc}
\hline \multirow{2}{*}{ Parameter } & \multicolumn{3}{c}{ Signifikansi } \\
\cline { 2 - 4 } & Perlakuan & $\begin{array}{c}\text { Uji } \\
\text { Skoring }\end{array}$ & $\begin{array}{c}\text { Uji } \\
\text { Hedonik }\end{array}$ \\
\hline & Konsentrasi & S & S \\
\cline { 2 - 4 } & Waktu & S & S \\
\cline { 2 - 4 } & Interaksi & NS & NS \\
\cline { 2 - 4 } & Konsentrasi & S & S \\
\cline { 2 - 4 } & Waktu & S & NS \\
\cline { 2 - 4 } & Interaksi & NS & NS \\
\hline & Konsentrasi & S & NS \\
\cline { 2 - 4 } & Waktu & S & S \\
\cline { 2 - 4 } & Interaksi & NS & NS \\
\hline
\end{tabular}

Keterangan : S : Signifikan

NS : Non Signifikan

Table 2 menunjukkan bahwa perlakuan konsentrasi dan lama perendaman ekstrak $S$. crassifolium memberikan pengaruh yang signifikan terhadap kenampakan cangkang baik secara skoring maupun hedonik. Konsentrasi ekstrak $S$. crassifolium memberikan hasil yang signifikan terhadap nilai skoring dan hedonik, sedangkan perlakuan lama perendaman memberikan hasil yang signifikan terhadap nilai skoring tetapi tidak signifikan pada nilai hedonik terhadap aroma cangkang. Pada parameter aroma isi telur, perlakuan konsentrasi ekstrak $S$. crassifolium memberikan pengaruh yang signifikan pada nilai skoring tetapi tidak signifikan pada nilai hedonik, tetapi pada perlakuan lama perendaman memberikan pengaruh yang signifikan pada nilai skoring dan hedonik. Interaksi antara konsentrasi dan lama 
Versi Online:

http://Www.profood.unram.ac.id/index.php/profood e-ISSN: $2443-3446$

perendaman ekstrak $S$. crassifolium memberikan pengaruh yang non signifikan terhadap kenampakan cangkang, aroma cangkang, maupun aroma isi telur.

\section{Kenampakan Cangkang}

Hasil analisa uji lanjut dari perlakuan yang memberikan hasil signifikan terhadap kenampakan telur dapat diamati pada Tabel 3-6.

Tabel 3. Hasil Uji Lanjut BNJ 5\% Pengaruh Konsentrasi $S$. crassifolium Terhadap Kenampakan Cangkang Telur Ayam Kampung Konsumsi Secara Skoring

\begin{tabular}{|c|l|r|c|}
\hline Ranking & Konsentrasi & Purata & $\begin{array}{c}\text { Signifik } \\
\text { ansi }\end{array}$ \\
\hline 1 & $0 \%$ & 4,5 & a \\
\hline 2 & $20 \%$ & 3,417 & b \\
\hline 3 & $40 \%$ & 3,13 & bc \\
\hline 4 & $60 \%$ & 2,867 & c \\
\hline
\end{tabular}

Tabel 4. Hasil Uji Lanjut BNJ 5\% Pengaruh Waktu Perendaman Terhadap Kenampakan Cangkang Telur Ayam Kampung Konsumsi Secara Skoring

\begin{tabular}{|c|c|c|c|}
\hline Ranking & Waktu & Purata & Signifikansi \\
\hline 1 & 30 menit & 3,837 & a \\
\hline 2 & 60 menit & 3,325 & b \\
\hline 3 & 90 menit & 3,275 & b \\
\hline
\end{tabular}

Berbagai konsentrasi dan lama perendaman telur ayam kampung dengan ekstrak $S$. crassifolium memberikan pengaruh yang berbeda nyata secara skoring terhadap kenampakan cangkang telur ayam kampung. Hubungan pengaruh konsentrasi dan lama perendaman ekstrak $S$. crassifolium terhadap kenampakan telur ayam kampung secara skoring dapat diamati pada Tabel 3 dan 4.

Tabel 3 menunjukkan bahwa skor tertinggi pengaruh konsentrasi ekstrak $S$. crassifolium terhadap kenampakan cangkang telur ayam kampung adalah perlakuan $0 \%$ dengan skor 4,5 yang menunjukkan bahwa cangkang tetap berwarna putih khas telur ayam kampung sedangkan perlakuan konsentrasi $60 \%$ memperoleh skor terendah yaitu 2,867 yang menunjukkan bahwa kenampakan telur semakin tidak berwarna khas telur ayam kampung.
Pro Food (Jurnal IImu dan Teknologi Pangan)

Vol 7 No. 1 Mei 2021

ISSN: 2443-1095

Perlakuan $20 \%$ berbeda nyata dengan perlakuan $0 \%$ tetapi tidak berbeda nyata dengan perlakuan $40 \%$ yaitu dengan skor 3,417 yaitu agak berwarna khas telur ayam kampung.

Tabel 4 menunjukkan bahwa waktu perendaman 30 menit menghasilkan skor tertinggi yaitu 3,837 yang menunjukkan bahwa cangkang telur berwarna khas telur sedangkan lama perendaman 90 menit menunjukkan skor terendah yaitu 3,27 yang menunjukkan cangkang telur agak berwarna khas telur ayam kampung. Perlakuan perendaman 90 menit tidak berbeda nyata dengan perlakuan perenaman 60 menit yaitu agak berwarna khas telur. Semakin tinggi konsentrasi dan semakin lama perendaman ekstrak $S$. crassifolium memberikan hasil skor yang semakin rendah terhadap nilai skoring kenampakan cangkang telur. Hal ini disebabkan bercak berwarna kehitaman yang ditinggalkan oleh sisa larutan ekstrak $S$. crassifolium yang masih menempel pada cangkang telur. Semakin tinggi konsentrasi dan semakin lama perendaman maka semakin banyak bercak hitam yang dihasilkan karena semakin banyak larutan ekstrak S. crassifolium yang menempel dan diserap oleh pori-pori cangkang telur. Cangkang memiliki ribuan pori-pori yang berfungsi sebagai jalur pertukaran gas. Pori-pori tersebut memiliki ukuran 10-70 $\mu \mathrm{m}$ dan tersebar di seluruh permukaan cangkang (Harahap, 2007).

Tabel 5. Hasil Uji Lanjut BNJ 5\% Pengaruh Konsentrasi Terhadap Kenampakan Cangkang Telur Ayam Kampung Konsumsi Secara Hedonik

\begin{tabular}{|c|l|r|c|}
\hline Ranking & Konsentrasi & Purata & Signifikansi \\
\hline 1 & $0 \%$ & 4.183 & a \\
\hline 2 & $20 \%$ & 2.983 & b \\
\hline 3 & $40 \%$ & 2.63 & bc \\
\hline 4 & $60 \%$ & 2.45 & c \\
\hline
\end{tabular}

Tabel 6. Hasil Uji Lanjut BNJ 5\% Pengaruh Waktu Terhadap Kenampakan Cangkang Telur Ayam Kampung Konsumsi Secara Hedonik

\begin{tabular}{|c|c|c|c|}
\hline Ranking & Waktu & Purata & Signifikansi \\
\hline 1 & 90 menit & 3.325 & a \\
\hline 2 & 60 menit & 2.9375 & b \\
\hline 3 & 30 menit & 2.925 & b \\
\hline
\end{tabular}


Versi Online:

http://www.profood.unram.ac.id/index.php/profood e-ISSN: 2443-3446

Tabel 5 menunjukkan skor hedonik kenampakan cangkang telur ayam kampung dimana diperoleh perlakuan perendaman $0 \%$ ekstrak $S$. crassifolium dengan skor tertinggi 4,183 yaitu disukai panelis dan skor terendah yaitu perlakuan perendaman $60 \%$ ekstrak $S$. crassifolium dengan skor 2,45 yang menyatakan bahwa tidak disukai panelis.

Table 6 menunjukkan skor hedonik kenampakan telur berdasarkan waktu perendaman. Skor tertinggi diperoleh perlakuan 90 menit dengan skor 3,325 yang menunjukkan bahwa tidak disukai panelis. Dan skor terendah diperoleh perlakuan perendaman 30 menit dengan skor 2,925 yang menyatakan bahwa kenampakan telur ayam kampung tidak disukai panelis. Semakin tinggi konsentrasi dan semakin lama waktu perendaman ekstrak $S$. crassifolium menyebabkan panelis tidak menyukai kenampakan cangkang telur. Hal ini disebabkan panelis tidak menyukai bercak kehitaman yang ditinggalkan oleh ekstrak $S$. crassifolium pada cangkang telur.

\section{Aroma Cangkang}

Hasil uji lanjut pengaruh konsentrasi dan lama perendaman ekstrak $S$. crassifolium terhadap aroma cangkang telur ayam kampung secara skoring maupun hedonik dapat diamati pada table 7-8.

Tabel 7. Hasil Uji Lanjut BNJ 5\% Pengaruh Konsentrasi Terhadap Aroma Cangkang Telur Ayam Kampung Konsumsi Secara Skoring

\begin{tabular}{|c|l|r|c|}
\hline Ranking & Konsentrasi & Purata & Signifikansi \\
\hline 1 & $0 \%$ & 3.483 & a \\
\hline 2 & $20 \%$ & 2.3 & b \\
\hline 3 & $40 \%$ & 1.9 & c \\
\hline 4 & $60 \%$ & 1.83 & c \\
\hline
\end{tabular}

Tabel 8. Hasil Uji Lanjut BNJ 5\% Pengaruh Waktu Terhadap Aroma Cangkang Telur Ayam Kampung Konsumsi Secara Skoring

\begin{tabular}{|c|c|r|c|}
\hline Ranking & Waktu & Purata & Signifikansi \\
\hline 1 & 30 menit & 2.66 & a \\
\hline 2 & 60 menit & 2.36 & ab \\
\hline 3 & 90 menit & 2.14 & b \\
\hline
\end{tabular}

Pro Food (Jurnal IImu dan Teknologi Pangan)

Vol 7 No. 1 Mei 2021

ISSN: 2443-1095

Berdasarkan Tabel 7 dapat diamati bahwa skor tertinggi terhadap aroma cangkang telur ayam kampung berdasarkan konsentrasi ekstrak S. crassifolium diperoleh dari perlakuan $0 \%$ dengan skor 3,48 yang menunjukkan agak beraroma khas telur. Skor terendah diperoleh perlakuan konsentrasi $60 \%$ dengan lama dengan skor 1,85 yang menunjukkan beraroma rumput laut. Perlakuan $20 \%$ dan $40 \%$ masing-masing memperoleh skor 2,3 dan 1,8 dimana masingmasing menunjukkan beraroma rumput laut.

Berdasarkan Tabel 8 dapat diamati bahwa skor tertinggi cangkang telur ayam kampung berdasarkan waktu perendaman diperoleh dari perlakuan lama perendaman 30 menit dengan skor 2,66 yang menunjukkan agak beraroma khas telur. Skor terendah diperoleh perlakuan perendaman 90 menit dengan skor 2,14 yaitu beraroma rumput laut.

Semakin tinggi konsentrasi dan semakin lama perendaman telur ayam kampung dengan ekstrak $S$. crassifolium menyebabkan aroma cangkang telur semakin beraroma rumput laut. Hal ini disebabkan semakin banyaknya ekstrak $S$. crassifolium yang menyerap pada cangkang telur, selain meninggalkan bercak kehitaman, ekstrak $S$. crassifolium juga meninggalkan aroma rumput laut. Semakin banyak bercak kehitaman semakin kuat aroma rumput laut yang dihasilkan.

Tabel 9. Hasil Uji Lanjut BNJ 5\% Pengaruh Konsentrasi Terhadap Aroma Cangkang Telur Ayam Kampung Konsumsi Secara Hedonik

\begin{tabular}{|c|l|r|c|}
\hline Ranking & Konsentrasi & Purata & Signifikansi \\
\hline 1 & $0 \%$ & 3.35 & a \\
\hline 2 & $20 \%$ & 2.9 & b \\
\hline 3 & $40 \%$ & 2.867 & b \\
\hline 4 & $60 \%$ & 2.767 & b \\
\hline
\end{tabular}

Tabel 10. Hasil Uji Lanjut BNJ 5\% Pengaruh Konsentrasi Terhadap Aroma Cangkang Telur Ayam Kampung Konsumsi Secara Hedonik

\begin{tabular}{|c|c|r|c|}
\hline Ranking & Waktu & Purata & Signifikansi \\
\hline 1 & 30 menit & 3.08 & a \\
\hline 2 & 60 menit & 2.94 & a \\
\hline 3 & 90 menit & 2.88 & a \\
\hline
\end{tabular}


Versi Online:

http://www.profood.unram.ac.id/index.php/profood e-ISSN: 2443-3446

Dari Tabel 9 dapat diamati bahwa skor hedonik tertinggi aroma cangkang telur berdasarkan konsentrasi ekstrak $S$. crassifolium diperoleh perlakuan konsentrasi $0 \%$ dengan skor 3,35 yaitu agak disukai panelis. Skor terendah diperoleh dari perlakuan konsentrasi 60\% dengan skor 2,767 yaitu agak tidak disukai panelis. Perlakuan $20 \%$ dan $40 \%$ tidak berbeda nyata dengan perlakuan $60 \%$ yaitu agak tidak disukai panelis.

Tabel 10 menunjukkan skor hedonik perlakuan lama perendaman terhadap aroma cangkang telur berdasarkan lama perendaman. Semua perlakuan lama perendaman menunjukkan hasil yang tidak berbeda nyata yaitu agak tidak disukai panelis. Semakin tinggi konsentrasi dan semakin lama perendaman semakin menurunkan kesukaan panelis terhadap aroma cangkang telur ayam kampung. Hal ini disebabkan karena aroma telur menjadi semakin beraroma rumput laut dan panelis kurang menyukai aroma rumput pada cangkang telur ayam kampung. Aroma rumput laut ini disebabkan semakin tinggi konsentrasi dan lama perendaman semakin banyak ekstrak $S$. crassifolium yang terserap oleh cangkang yang menyebabkan aroma rumput laut semakin kuat.

\section{Aroma isi telur}

Hasil uji lanjut pengaruh konsentrasi dan lama perendaman ekstrak $S$. crassifolium terhadap aroma isi telur ayam kampung secara skoring maupun hedonik dapat diamati pada table 10-14.

Tabel 11. Hasil Uji Lanjut BNJ 5\% Pengaruh Konsentrasi Terhadap Aroma Isi Telur Ayam Kampung Konsumsi Secara Skoring

\begin{tabular}{|c|l|r|c|}
\hline Ranking & Konsentrasi & Purata & Signifikansi \\
\hline 1 & $0 \%$ & 3.483 & a \\
\hline 2 & $20 \%$ & 3.1167 & ab \\
\hline 3 & $40 \%$ & 2.73 & b \\
\hline 4 & $60 \%$ & 2.717 & b \\
\hline
\end{tabular}

Pro Food (Jurnal Ilmu dan Teknologi Pangan)

Vol 7 No. 1 Mei 2021

ISSN: 2443-1095

Tabel 12. Hasil Uji Lanjut BNJ 5\% Pengaruh Konsentrasi Terhadap Aroma Isi Telur Ayam Kampung Konsumsi Secara Skoring

\begin{tabular}{|c|c|r|c|}
\hline Ranking & Waktu & Purata & Signifikansi \\
\hline 1 & 90 menit & 3.175 & $\mathrm{a}$ \\
\hline 2 & 60 menit & 3.063 & $\mathrm{ab}$ \\
\hline 3 & 30 menit & 2.8 & $\mathrm{~b}$ \\
\hline
\end{tabular}

Tabel 11 menunjukkan skor aroma isi telur berdasarkan konsentrasi ekstrak $S$. crassifolium. Skor tertinggi diperoleh dari perlakuan 0\% dengan skor 3,483 yaitu agak beraroma khas telur. Perlakuan $20 \%$ tidak berbeda nyata dengan semua perlakuan dengan skor 3,1 yaitu agak beraroma khas telur. Skor terendah diperoleh dari perlakuan konsentrasi $60 \%$ dengan skor 2,7 yaitu agak beraroma khas telur.

Tabel 12 menunjukkan pengaruh lama perendaman terhadap nilai skoring aroma isi telur ayam kampung dimana skor tertinggi diperoleh dari perlakuan perendaman 90 menit dengan skor 3,175 yaitu agak beraroma khas telur. Skor terendah diperoleh dari perlakuan lama perendaman 30 menit dengan skor 2,8 yaitu agak beraroma khas telur. Hasil ini menunjukkan bahwa semakin tinggi konsentrasi dan semakin lama perendaman telur ayam kampung dengan esktrak $S$. crassifolium memberikan hasil agak beraroma khas telur. Berbeda dengan cangkang telur, isi telur tidak menujukkan aroma rumput laut seperti halnya cangkang telur. Hal ini disebabkan karena esktrak $S$. crassifolium hanya mencapai bagian cangkang saja dan tidak masuk dan mempengaruhi putih maupun kuning telur karena bagian isi telur dilindungi oleh lapisan membran.

Hasil uji hedonik aroma isi telur terhadap aroma isi telur dapat diamati pada tabel 13-14. Tabel 13 menunjukkan hubungan konsentrasi esktrak $S$. crassifolium terhadap nilai hedonik aroma isi telur. Semua perlakuan menunjukkan hasil yang tidak berbeda nyata yaitu agak disukai panelis. 
Versi Online:

http://Www.profood.unram.ac.id/index.php/profood e-ISSN: 2443-3446

Tabel 13. Hasil Uji Lanjut BNJ 5\% Pengaruh Konsentrasi Terhadap Aroma Isi Telur Ayam Kampung Konsumsi Secara Hedonik

\begin{tabular}{|c|l|r|c|}
\hline Ranking & Konsentrasi & Purata & Signifikansi \\
\hline 1 & $0 \%$ & 3.25 & a \\
\hline 2 & $40 \%$ & 3.15 & a \\
\hline 3 & $60 \%$ & 3.133 & a \\
\hline 4 & $20 \%$ & 3.033 & a \\
\hline
\end{tabular}

Tabel 14. Hasil Uji Lanjut BNJ 5\% Pengaruh Konsentrasi Terhadap Aroma Isi Telur Ayam Kampung Konsumsi Secara Hedonik

\begin{tabular}{|c|c|r|c|}
\hline Ranking & Waktu & Purata & Signifikansi \\
\hline 1 & 90 menit & 3.3375 & $\mathrm{a}$ \\
\hline 2 & 60 menit & 3.1 & $\mathrm{ab}$ \\
\hline 3 & 30 menit & 2.9875 & $\mathrm{~b}$ \\
\hline
\end{tabular}

Tabel 14 menunjukkan hubungan waktu perendaman esktrak $S$. crassifolium terhadap hedonik isi telur. Skor tertinggi diperoleh dari perlakuan lama perendaman selama 90 menit dengan skor 3,3375 dan skor terendah diperoleh dari perlakuan lama perendaman selama 30 menit dengan skor 2,9875 yaitu agak disukai panelis. Hasil dari analisa hedonik aroma isi telur agak disukai panelis karena esktrak $S$. crassifolium tidak memberikan aroma khas rumput laut terhadap putih maupun kuning telur karena esktrak $S$. crassifolium hanya terserap oleh pori-pori pada cangkang telur saja dan tidak masuk hingga kedalam isi telur.

\section{KESIMPULAN}

Berdasarkan uraian pembahasan yang terbatas pada lingkup penelitian maka dapat diambil kesimpulan bahwa perendaman telur ayam kampung dengan ekstrak etanol $S$. crassifolium memberikan pengaruh yang tidak berbeda nyata terhadap $\mathrm{pH}$ kuning dan putih telur dan aroma isi telur tetapi memberikan pengaruh berbeda nyata terhadap kenampakan cangkang dan aroma cangkang. Perlakuan terbaik diperoleh dari perlakuan perendaman dengan konsentrasi $20 \%$ ekstrak etanol $S$. crassifolium dengan lama perendaman selama 60 menit, dimana diperoleh $\mathrm{pH}$ kuning dan putih
Pro Food (Jurnal IImu dan Teknologi Pangan)

Vol 7 No. 1 Mei 2021

ISSN: 2443-1095

telur masing-masing 6,28 dan 8,86. Kenampakan warna khas telur dan disukai panelis, aroma cangkang khas telur dan disukai panelis serta aroma isi telur yang agak beraroma khas telur dan agak disukai panelis.

\section{DAFTAR PUSTAKA}

Afiyah, D. N. dan Rahmawati, N., 2017. Kualitas Fisik Dan Mikrobiologi Telur Ayam Ras Di Pasar Tradisional Kota Kediri. Seminar Nasional Hasil Penelitian Universitas Kanjuruhan Malang. Universitas Kanjuruhan. Malang.

Amaro, M., Ariyana, M.D., Widyastuti, S., Nazaruddin, Handayani, B. R., dan Werdiningsih, W., 2018. Aktivitas Antibakteri Ekstrak Sargassum Crassifolium dari Perairain NTB. Laporan Penelitian $P N B P$. Universitas Mataram,

Bachtiar, S.Y., Tjahjaningsih, W dan Sianita, N., 2012. Pengaruh Ekstrak Alga Cokelat (Sargassum sp.) Terhadap Pertumbuhan Bakteri Escherichia coli. Journal of Marine and Coastal Science, 1(1), $53-60$.

Baleta, F. N., Bolanos, J. M., Ruma, O. C., Baleta, A. N., dan Cairel, J. D., 2017. Phytochemicals Screening and Antimicrobial Properties of Sargassum oligocystum and Sargassum crassifolium Extracts. Journal of Medicine Plants Studies. 5(1):382-387.

Chusniati, S., Budiono, R. N., dan Kurnijasanti, R., 2009. Deteksi Salmonella $s p$ pada Telur Ayam Buras yang Dijual Sebagai Campuran Jamu di Kecamatan Sidoarjo. Journal of Poultry Diseases. 2(1):20-23.

Diaz. D. 2008. Safety And Efficacy Of Ecobiol As Feed Addtitive For Chickhen For Fattening. The EFSA Journal. 773: 2-13.

Djafar, T. F. dan Siti., 2007. Cemaran Mikroba Pada Produk Pertanian Penyakit Yang Ditumbulkan Dan Pencegahannya. Jurnal Litbang Pertanian. 26(2):67-75.

Finata, R.P., D.R. Mas, dan K.S. I Gusti. 2015. Pengaruh Lama Penyimpanan Pada Suhu 
Versi Online:

http://Www.profood.unram.ac.id/index.php/profood e-ISSN: 2443-3446

Kamar Telur Itik Segar Dan Telur Yang Mengalami Pengasinan Ditinjau Dari Jumlah Eschericia coli. Buletin Veteriner Udayana. 7(1):41-4

Haryoto, 1996. Teknologi Tepat Guna Pengawetan Telur Segar. Kanisius. Yogyakarta.

Hiroko, S.P., T. Kurtini, dan Riyanti. 2014. Pengaruh Lama Simpan Dan Warna Kerabang Telur Ayam Ras Terhadap Indeks Albumen, Indeks Yolk Dan Ph Telur. Skripsi. Fakultas Pertanian, Universitas Lampung, Lampung.

Kereh, V. G., Kusnandar, F., Wibawan, I. W. T., dan Nahrowi, 2018. Karakteristik Kimia Ekstrak Rumput Laut Serta Kemampuannya Menghambat Bakteri Salmonella sp. Jurnal Veteriner. 19(4): 467-477.

King, B., Warren, A., Mueller, C., 2004. Health Hazard Evaluation Report. National Institute for Occupational Safety and Health.

Nurjanna, S. 2015. Kontaminasi Bakteri Telur Ayam Ras Yang Dipelihara Dengan Sistem Pemeliharaan Intensif Dan Free Range Dengan Waktu Pemberian Naungan Alami Berbeda. Skripsi. Fakultas Perternakan, Universitas Hasanuddin, Makassar

Omwandho, C. O. A. dan Kubota T., 2010. Salmonella enterica Serovar Enteritidis A Mini Riview of Contamination Routes and Limitations to Efective Control. JARQ. 44:716.

Rahayu, P. dan Winanti., 2000. Aktivitas Mikroba. Bumbu Masakan Tradisional Hasil Olahan Industri Terhadap Bakteri Patogen dan Perusak. Buletin Teknologi dan Industri Pangan. 11(2).

Sarwono, B., 1995. Pengawetan dan Pemanfaatan Telur. Swadaya. Jakarta.

Stadelman, W. J. and O.J. Cotteril, 1973. Egg Science and Technology. Mac Millan Publisher, UK.
Pro Food (Jurnal IImu dan Teknologi Pangan)

Vol 7 No. 1 Mei 2021

ISSN: 2443-1095

Sulistiati. 2003. Pengaruh Berbagai Macam Pengawet dan Lama Penyimpanan terhadap Kualitas Telur Konsumsi. Skripsi. Fakultas Peternakan, Institut Pertanian Bogor. Bogor.

Tayel, A. A., El-Sedfy, M. A., Ibrahim, A. I., Moussa, S. H., 2018. Application of Quercus Infectoria Extract As A Natural Antimicrobial Agent For Chicken Egg Decontamination. Revista Argentina De Microbiología. 50(4): 391- 397. 